\title{
The Effect of Individualized Technology-Mediated Feedback on EFL Learners' Argumentative Essays
}

Fatemeh Soltanpour ${ }^{1 *}$, Mohammadreza Valizadeh ${ }^{2}$

${ }^{1}$ English Department, Kar Higher Education Institute, PO box 1571, Qazvin, Iran

${ }^{2}$ English Department, Faculty of Foreign Languages, Gazi University, PO Box 06500, Ankara, Turkey

Corresponding Author: Fatemeh Soltanpour, E-mail: fatemeh.soltanpour@gmail.com

\section{ARTICLE INFO}

Article history

Received: October 19, 2017

Accepted: January 09, 2018

Published: May 01, 2018

Volume: 7 Issue: 3

Advance access: March 2018

Conflicts of interest: None

Funding: None

\begin{abstract}
This quantitative quasi-experimental study, which followed a pretest-posttest-delayed posttest design, was aimed at investigating the effect of individualized technology-mediated feedback (henceforth, ITMF) on the overall quality of Iranian EFL learners' argumentative essays. The effect of ITMF, as the experimental treatment, was compared with the common written corrective feedback (henceforth, CWCF) strategies as the control treatment. 57 learners, studying at general EFL courses at upper-intermediate level, formed the participants. They were assigned to two groups: ITMF and CWCF, which, in this study, is meant as the pen-and-paper form of direct and indirect feedback. Each group received six sessions of treatment. The writing tasks and tests were all of argumentative type. First, whether there was any significant difference between the ITMF and CWCF in the overall quality of the essays was investigated. The ITMF group significantly outperformed the CWCF one. Then, whether the difference between the groups varied over time was explored, and it was revealed that the ITMF was still significantly superior over the CWCF. Next, whether there would be any significant change in the ITMF in the long term was examined, and no change was seen. The study supports the advocates of screencasting feedback, revision and teacher-learner negotiation following the feedback.
\end{abstract}

Key words: Written Corrective Feedback, Technology-Mediated Feedback, Individual Differences, Camtasia, Argumentative Essays, Revision, Teacher-Learner Negotiation

\section{INTRODUCTION}

Feedback has been considered a crucial element to the process of learning (K. Hyland, 2009) and in second language (henceforth, L2) writing courses (Ferris, 2014) not only for its potential for the development of L2 writing skills, but also for enhancing student motivation (K. Hyland \& Hyland, 2006a). In addition, previous studies have consistently revealed evidence that $\mathrm{L} 2$ learners have positive attitudes towards teacher's correction of their written texts and demand the provision of written corrective feedback (henceforth, WCF) (Alkhatib, 2015; Chandler, 2003; Chen, Nassaji, \& Liu, 2016; Cohen \& Cavalcanti, 1990; Cumming, 1995; Diab, 2005a, 2005b, Ferris, 1995, 2004; Ferris \& Roberts, 2001; Grami, 2005; Hajian, Farahani, \& Shirazi, 2014; Hamouda, 2011; Hedgcock \& Lefkowitz, 1994, 1996; F. Hyland, 1998; Lee, 1997, 2004; Leki, 1991; Mahfoodh \& Pandian, 2011; Zacharias, 2007); on the other hand, many L2 learners have also faced difficulties understanding some of their instructors' comments (Alkhatib, 2015; Conrad \& Goldstein, 1999; Ferris, 1995; Hedgcock \& Lefkowitz, 1994; F. Hyland, 2003; Lee, 2008). Considering the teachers, producing the type of feedback that is not only clear and pre- cise for students to interpret but also efficient and practical enough for the teachers to offer is difficult (Carless, Salter, Yang, \& Lam, 2011). As a result, teachers and researchers have always been concerned about the most effective way of providing feedback to L2 learners' written texts (McMartin-Miller, 2014).

Besides, Dörnyei (2005) stated that individual differences (henceforth, IDs) are the "consistent predictors of L2 learning success" (p. 6). Regarding the writing skill, as it is a complex process requiring the skillful coordination of both cognitive and linguistic processes and resources (Hayes, 1996; Kellogg, 1996), it is expected that learners with different cognitive abilities "execute and orchestrate these processes with varying degrees of efficiency and differ in how they learn to write in another language" (Kormos, 2012, p. 390). In addition, according to Sheen (2011), "ID variables - such as language aptitude, anxiety, and attitudes towards corrective feedback - influence learners' receptivity to error correction and thus the effectiveness of the feedback" (p. 129); these variables can affect the process of language learning and the subsequent outcomes of language instruction (Sheen, 2011). Consequently, individual and contextual factors are very important in the debate over the effective- 
ness of the WCF (Chen et al., 2016; Evans, Hartshorn, McCollum, \& Wolfersberger, 2010; F. Hyland, 1998, 2000; K. Hyland \& Hyland, 2006b); in brief, the type of feedback that is effective for one student in one setting is less so in another context (K. Hyland \& Hyland, 2006a) due to the individual and contextual factors.

For instance, differences in learners' learning styles can either support or inhibit the learners' intentional cognition and active engagement (Katayama, 2007) and thus such differences can strongly contribute to the efficacy of corrective feedback (Cohen, 2012; Ferris, 2010). If teachers are aware of their students' learning styles, they will be able to apply appropriate techniques that suit the learners' preferences (Leki, 1991), thereby contributing to improvement in the learners' learning, attitudes, behavior, and motivation (Ferris, 2003).

Moreover, scholars have rightly emphasized the crucial role of motivation (Bruton, 2009; Ferris, 2010; Guénette, 2007; F. Hyland, 2010; Kormos, 2012; Van Beuningen, 2010); for example, Guénette (2007) said, "If the students are not committed to improving their writing skills, they will not improve, no matter what type of corrective feedback is provided." (p. 52) Furthermore, F. Hyland (2003, 2010), Van Beuningen (2010), and Kormos (2012) argued that motivation affects learners' attention devoted to the received feedback and their involvement in required writing tasks.

Additionally, the language learning goals which learners plan to attain contribute importantly to the establishment of attitudes to L2 writing tasks (Kormos, 2012) and both factors of goals and attitudes to writing affect how learners value the L2 writing activity (Manchón, 2011) because they affect the individual's "use of meta-cognitive operations, which can regulate what and how much effort one is willing to make to engage with WCF" (Han \& Hyland, 2015, p. 40), so they are also instrumental in writing-related self-efficacy beliefs (Manchón, 2009). The feedback that students receive can also affect their self-efficacy beliefs (Kormos, 2012; Manchón, 2009).

Given the above-mentioned facts, in order for classroom practice to be effective, "it must be flexible enough to incorporate the preferences and needs of the language learners" (Oladejo, 1993, p. 71). If the teachers' instructions are catered to the learners' perceived needs, the students will develop a positive attitude toward what they are learning (Oladejo, 1993) because learners' emotional responses (i.e., affective reactions to teacher's WCF) can affect their understanding and utilization of the WCF provided (Mahfoodh, 2017). Consequently, teachers, whose goal is not simply correcting the errors for the learners, but intend to give formative feedback to help learners "improve learning, to motivate them, and to make them autonomous writers in the long run" (Lee, 2014, p. 208), have to think carefully before giving feedback (F. Hyland, 2010; Lee, 2013); thus, a onesize-fits-all behavior had better not be adopted and the learners' individual needs must be considered (Guénette, 2012; Lee, 2013, 2014).

Moreover, it has been strongly recommended that the learners be actively engaged (Havnes, Smith, Dysthe, \& Ludvigsen, 2012) and that feedback be provided in a negotiated and interactive manner (Nassaji, 2011; Nicol, 2010), so that it would become more effective "because in such cases the feedback can become more fine-tuned and adjusted to the learner's level of interlanguage" (Nassaji, 2011, p. 317); therefore, the learners will feel more motivated (Katayama, 2007).

The researchers in this study had all the mentioned issues in mind, but it should be noted that, in real classrooms, it is really difficult to differentiate the feedback for every individual student with varying levels of interest, goal, learning styles, etc.; Ellis and Shintani (2014) also pinpointed this challenge the teachers face; additionally, the high numbers of students in a class can be a barrier to conducting the negotiation (Nicol, 2010). Despite these, teachers need to come up with a solution to create a supportive context for the learners.

In light of all the above-mentioned issues, and as the researchers in this study intended to adopt an appropriate approach to providing feedback, the use of e-feedback has been noticed in the literature, as a technique which can be highly effective (Ene \& Upton, 2014), especially if it is provided in combination with face-to-face conferencing (Matsumura \& Hann, 2004). Veedback (i.e., feedback prepared by video captures) provides the opportunity for learners to see their work, listen to teachers' recorded comments, watch the written or highlighted points (AbdRahman, Salam, \& Yusof, 2014) and correct their essays. Veedback can improve students' writing meaningfully by providing them with more information on their writings in comparison to WCF (Silva, 2012; Thompson \& Lee, 2012); students can reflect on their writing and revise their texts based on feedback they received, so they will be engaged actively in writing (Cumming, 2015); moreover, veedback is easy to understand and by using such feedback different learning styles can be met (Mayer \& Moreno, 2003; Silva, 2012; Thompson \& Lee, 2012), so such feedback has been found to be motivating (Henderson \& Phillips, 2015).

Furthermore, some studies have revealed that students found video feedback as more valid and valuable than WCF and had positive attitude towards it (Ali, 2016; Crews \& Wilkinson, 2010; Crook et al., 2012; Denton, Madden, Roberts, \& Rowe, 2008; Henderson \& Phillips, 2015; Jones, Georghiades, \& Gunson, 2012); for instance, the students in Henderson and Phillips's (2015) study, mentioned that video feedback was individualized, supportive, caring, motivating, clear, detailed, unambiguous, prompting reflection, and thus constructive.

All these inspired the researchers of the current study to employ an approach which consider nearly all the above-mentioned scholarly recommendations. Hence, the technique of ITMF, taking the stated points into consideration, was compared with common CWCF strategies (i.e., pen-and-paper form of direct and indirect WCF). The details of the ITMF are going to be explained in the Procedure Section.

\section{Research Question}

This study has addressed the following question:

Is there any significant difference between the ITMF group and CWCF one in the overall quality of their argumentative essays? If so, does the difference between groups 
vary over time? If one group proves to be superior, will there be any significant change in it in the long term?

\section{Theoretical Background}

In the present study, following Lee's (2014) comments, the teacher-researcher attempted to mediate the feedback for the learners in the ITMF group by "directing their attention to the strategies needed to solve their problems in writing" (p. 204) during the interaction she had with the students. Moreover, the students were not passive recipients of feedback; they actively involved in the process, as suggested by Van Beuningen (2010), Nassaji (2011), and Lee (2014). By teacher's help, and through the process of negotiation, they were able to understand not only the importance of the writing task and feedback but also their own strengths and weaknesses; they could also learn what to "do to close the gaps (i.e., improve the weaknesses) in their writing" (Lee, 2014 , p. 204). This view is in line with sociocultural paradigm for providing feedback which focuses on tailoring the feedback to the learners' zone of proximal development (ZPD), through a negotiated and graduated (i.e., adjusted to the level of the individual learner) process so that it would assist learning and also learners to self-correct (Aljaafreh \& Lantolf, 1994); as a result of this framework, learners have active roles in their learning and they are not passive recipients of feedback and can decide what and how they learn from it (F. Hyland, 1998, 2003; Storch \& Wigglesworth, 2010; Van Beuningen, 2010).

In addition, Vygotsky's sociocultural theory can be applied to CALL (Warschauer, 2005) because according to Vygotsky (1981, as cited in Warschauer, 2005), via mediation or the incorporation of tools or mediational means, the entire flow and structure of mental functions will alter; computer can be an example of those meditational means (Warschauer, 2005). CALL can also provide interactive learning environment in the L2 learning, which is in line with the social learning aspect of the Vygoskyian's theory (Warschauer, Turbee, \& Roberts, 1996).

Moreover, in this study, as an attempt was made to create opportunities for interaction and meaning negotiation, so the learners were provided with not only the input needed for acquiring language but also making the input more comprehensible for the learner, which is consistent with Long's (1996) Interaction Hypothesis. Through such interaction, the comprehensibility of the message (here, feedback) is enhanced (Pica, 1994).

Furthermore, the interactive learning environment, which is provided by CALL in the L2 learning, is also consistent with Long's (1996) Interaction Hypothesis and Ellis's (1999) perspective of interactionist SLA. According to Chapelle (2005), interaction in CALL takes place not only in face-to-face conversation between the learners and teacher as well as peers but also electronically over a computer, i.e., between the learner and the computer.

Moreover, the participating students were required to revise their essays after receiving feedback, which is supported by Swain's $(1985,1995)$ Output Hypothesis, based on which, if the learners are pushed to produce challenging output, their awareness of linguistic input and gaps is raised and thus their progress towards the target language is facilitated; the effectiveness of noticing the importance of input is also corroborated by Schmidt's (1990, 1995, 2001) Noticing Hypothesis.

\section{METHOD}

\section{Participants and Groupings}

Four intact classes of the Iranians, who were native speakers of Persian and students at upper-intermediate levels at an EFL learning institute, formed the participants of this intensive treatment. The participants were studying the book, entitled Summit 1 (Saslow \& Ascher, 2012). At the outset, there were 63 students, but six learners were absent for the posttest or delayed-posttest, so they were discarded, and totally, 57 participants (31 females and 26 males), ranging from 19 to 38 years old, formed the participants. Two of the classes, as Group 1, were given only the CWCF (i.e., a combination of pen-and-paper form of direct and indirect feedback), and the other two classes were given the ITMF. As a matter of fact, the ITMF group, in the form of a new approach in this study, recieved the experimental treatment, and the CWCF one received the control treatment.

\section{Instrumentation}

Three tests were used in each group: a pretest, a posttest, and a delayed-posttest of argumentative essay writing. Moreover, to evaluate the participants' essays, the IELTS Task 2 Writing Band Descriptors was used. Furthermore, the software Camtasia was utilized to provide the video feedback for the ITMF group.

\section{Design and Procedure}

Bitchener (2008) stated, "If a post-test is to be a valid measurement of progress, a comparable pre-test needs to be included in the research design." (p. 108). Moreover, if a delayed post-test is included in the design of the study, the validity of the findings will be sustained (Shintani \& Ellis, 2013). Therefore, the present study used a pretest-posttestdelayed-posttest design. Moreover, as recommended by Storch (2010), this study was conducted in real classrooms "within the context of an instructional program, with ecologically valid writing tasks" (p. 42). Therefore, because the non-random convenience sampling (i.e., intact classes) was used, the study is considered as quasi-experimental. Additionally, as both groups received feedback on their essays, in order to control the effects of the other factors as much as possible (Guénette, 2007; Lalande, 1982; Sheppard, 1992) the same teacher (i.e., the teacher-researcher) taught both groups; the book and writing topics were similar in both groups, as well.

The research was conducted in General English classes; the whole course lasted for 20 sessions (totally ten weeks), and each class lasted for 1 hour and 45 minutes. The focus of the courses was not merely writing, so the teacher-re- 
searcher had a schedule to do the study, which is indicated in Table 1.

On first session, the students in both groups wrote an essay of argumentative type, which was used as the pretest. It lasted for 40 minutes. Every week, the students in both groups were required to write an essay of argumentative type at home and hand it in to the teacher. Then, she provided the feedback for each group and offered it. All in all, both groups received six-session treatment. The posttest, which lasted for 40 minutes, was administered on a session in Week 7. Three weeks after administering the posttest, the delayed-posttest was done. Following Bitchener's (2008) comment, the participants were not told when the delayed post-test would be administered in order to eliminate the possibility of any student studying their personal notes or reviewing the video feedback. The teacher-researcher did not want the students to be prepared for the test beforehand.

\section{Procedure in the ITMF Group}

The procedure which was applied in the ITMF group is shown in Table 2.

Some points had better be mentioned: (1) Overall, the steps Jones, et al., (2012) described in their paper about the Screen Capture Digital Video procedure were followed, yet with some modifications. (2) To satisfy the students' different learning styles (Johnson \& Cooke, 2016) the feedback prepared was audio-visual in conjunction with the written one (i.e., the teacher typed and highlighted the necessary points while explaining them orally in video.). The teacher also opened and showed other relevant files and also inserted relevant links wherever it was needed in students' essays. (3) The learners, at their convenience, could receive the feedback earlier (i.e., before the second session of each week) by email or download it to their memory cards of their smart phones, tablets, or laptops in class on the $2^{\text {nd }}$ session of each week. This action was taken to overcome the challenge of slow loading time, with which the participants in AbdRahman et al.'s, (2014) and Ali's (2016) studies were faced.

\section{Procedure in the CWCF Group}

The procedure which was implemented in the CWCF group is indicated in Table 3.

\section{Types of Feedback}

The feedback provided included a combination of both direct and indirect ones as recommended by Lee (2013), due to the fact that "different types of errors do not react equally even to the same feedback treatment" (Nassaji, 2011, p. 317). For grammatical treatable errors, in Ferris's (2001) terms, the indirect feedback was used, by underlining or highlighting the error and giving the learners clues because such feedback makes the learners be more active and take responsibility for their learning and progress (Ashwell, 2000; Ellis, 2010; Ferris, 2001, 2006; F. Hyland, 2001; Lalande, 1982; Lee, 1997, 2013; Saito, 1994) given that the participants were upper-intermediate learners for whom offering the indirect feedback would be appropriate (Ellis, 2009a). Direct feedback was offered to untreatable errors as they could be difficult for the learners to self-correct these errors (Ferris, 2001).

The provided feedback was unfocused or comprehensive which is the most widely used type of feedback by teachers (Ferris, 2006; Guénette, 2012; Lee, 2004, 2008; Van Beuningen, 2010) and liked by the students in some previous studies (e.g. Lee, 2005; Leki, 1991; Oladejo, 1993), so the unfocused feedback is more ecologically valid than the fo-

Table 1. Research schedule

\begin{tabular}{lllll}
\hline Week $\mathbf{1}$ & Weeks 2, 3, 4, 5, 6 Treatment Period & Week $\mathbf{7}$ & Weeks $\mathbf{8}$ and $\mathbf{9}$ & Week 10 \\
\hline Pretest and & Essays 2, 3, 4, 5 followed by the feedback & Posttest & No work on Essay Writing & Delayed-Posttest \\
Essay 1 & & & & \\
\hline
\end{tabular}

Table 2. Treatment period procedure in the ITMF group

\begin{tabular}{|c|c|c|}
\hline Treatment Period & & Procedure \\
\hline \multirow[t]{2}{*}{ Week 1} & Session 1 & $\begin{array}{l}\text { After administering the pretest, the students received the first } \\
\text { assignment. They were required to write an essay of argumentative } \\
\text { type at home using MS word processor and emailed it to the teacher. }\end{array}$ \\
\hline & Session 2 & $\begin{array}{l}\text { The students received the video feedback. The participants were } \\
\text { required to watch the video, revise their essays at home and be } \\
\text { prepared for follow-up negotiation in next class. }\end{array}$ \\
\hline \multirow[t]{2}{*}{ Week 2} & Session 1 & $\begin{array}{l}\text { The follow-up negotiation, which generally lasted for } 45 \text { to } \\
50 \text { minutes, took place. The teacher checked the students' revisions. } \\
\text { The students could ask either their friends or the teacher their } \\
\text { questions to clarify any ambiguity. Afterwards, the learners were } \\
\text { given the second essay topic to write at home and emailed it to the } \\
\text { teacher. }\end{array}$ \\
\hline & Session 2 & The same procedure as Session 2 of Week 1 was applied. \\
\hline Weeks $3,4,5,6$ & Sessions $1 \& 2$ & The same procedure was implemented. \\
\hline
\end{tabular}


Table 3. Treatment period procedure in the CWCF group

\begin{tabular}{|c|c|c|}
\hline Treatment Period & & Procedure \\
\hline \multirow[t]{2}{*}{ Week 1} & Session 1 & The pretest was administered. \\
\hline & Session 2 & $\begin{array}{l}\text { The students received the first assignment. They were } \\
\text { required to write an essay of argumentative type at home } \\
\text { using MS word processor, print it and hand it in for next } \\
\text { session in class. }\end{array}$ \\
\hline \multirow[t]{2}{*}{ Week 2} & Session 1 & The teacher got the papers to provide the feedback on it. \\
\hline & Session 2 & $\begin{array}{l}\text { The teacher returned the corrected essays and gave the } \\
\text { learners the second essay topic to write at home and hand } \\
\text { it in. }\end{array}$ \\
\hline Weeks $3,4,5$ & Sessions $1 \& 2$ & The same procedure was followed. \\
\hline \multirow[t]{2}{*}{ Week 6} & Session 1 & $\begin{array}{l}\text { The teacher got the } 5^{\text {th }} \text { essay, but gave no more essay } \\
\text { writing assignment. }\end{array}$ \\
\hline & Session 2 & The teacher returned the corrected essays. \\
\hline
\end{tabular}

cused one. Additionally, the unfocused feedback is also concerned with the writing as a whole rather than the writing as a way of practicing grammar (Bruton, 2009; Van Beuningen, 2010), which was the aim of the researchers in the current study. Therefore, the comprehensive feedback serves the need for more authentic CF methodologies, which focus "on the accurate production of all aspects of writing, simultaneously" (Hartshorn et al., 2010, p. 89). In addition, in case the learners commit a range of written errors, "a limited CF focus does not address the need to individualize feedback according to students' different strengths and weaknesses" (Ferris, 2010, p. 192). Moreover, as the participants were the upper-intermediate ones, the unfocused WCF could be useful for them (Bitchener \& Ferris, 2012).

To consider the learners' behavioral engagement with the feedback (Ellis, 2010; Van Beuningen, 2010) and also hold them accountable for their learning (Guénette, 2012), they were required to revise their essays based on the teacher's feedback. In addition, revision and editing of the written texts after receiving feedback can be a helpful and perhaps necessary intermediate step toward the long-term acquisition of a specific feature (Ferris, 2004, 2010; Guénette, 2012; Sachs \& Polio, 2007).

The combination of feedback provision and classroom discussions was found to be effective in several previous studies (Goldstein \& Conrad, 1990; Lee, 2013; Nassaji, 2011; Nicol, 2010; Williams \& Severino, 2004) and liked by students (Hedgcock \& Lefkowitz, 1994), so in the present study, like the one done by Han and Hyland (2015), the students had the opportunity for classroom negotiation with their teacher and peers to clarify their misunderstandings and correct their errors, which would increase the potential for extending the ZPD of the learners and assisting them in learning. In addition, because the process of revision is not simple (Guénette, 2012) and the skill of self-editing must be taught and practiced (Bitchener \& Ferris, 2012; Ferris, 1995), the learners were taught and assisted to complete the process during the interaction.

Moreover, as recommended by Van Beuningen (2010), Lee (2013), as well as Han and Hyland (2015), two of the learning strategies that facilitate the processing of the feedback and help the learners improve their writing ability were also considered. First, as recommended by Lee (2013) and proved by Soltanpour and Valizadeh, (2017) the learners in both groups were required to write their essays in word-processor and use the feedback provided by it; in addition, the participants were told to keep a reflective notebook to take notes of their errors and review them during the revision process. Keeping an error book was recommended by F. Hyland (2003) and Ellis (2009b); the effectiveness of keeping personal reflective notes was also suggested by Guénette (2012) and proved by Suzuki (2012) as well as Soltanpour and Valizadeh (2017).

\section{The Scoring Procedure}

In order to prevent the possibility of the researcher's bias and considering the rater reliability (Mackey \& Gass, 2005), two raters, who were IELTS instructors and examiners, evaluated each essay independently, and the final score was the average score of the two raters.

\section{ANALYSES AND RESULTS}

\section{Inter-rater Reliability}

To assess the inter-rater reliability of the tests in the study, Cronbach alpha coefficient was utilized. Table 4 shows the results.

Table 4 indicates good and acceptable reliability indices.

\section{The Normality Tests}

The assumption of normality was examined through both the graphic of histogram and the numerical way recommended by Larson-Hall (2010); the ratio of skewedness and kurtosis over their respective standard errors, as well as the Kolmogorov-Smirnov and the Shapiro-Wilk tests were utilized as the numerical way of assessing the normality (Field, 2013; Larson-Hall, 2010). No tests of both groups enjoyed normal distribution as indicated by histograms and the mentioned numerical tests; the outcomes of skewness and kurtosis were not within the ranges of $+/-1.96$ (Field, 2013); The found Sig. values on the Kolmogorov-Smirnov and the Sha- 
Table 4. Inter-rater reliability

\begin{tabular}{lll}
\hline Groups & Tests & Indices \\
\hline CWCF & Pretest & 0.85 \\
& Posttest & 0.84 \\
& Delayed Posttest & 0.91 \\
ITMF & Pretest & 0.87 \\
& Posttest & 0.88 \\
& Delayed Posttest & 0.95 \\
\hline
\end{tabular}

piro-Wilk tests were less than.05. As a result, the relevant non-parametric tests were used to find the answers to the research questions.

\section{Ensuring the Homogeneity of the Groups}

A Mann-Whitney $U$ test was run to compare the pretests in CWCF and ITMF groups to find out whether the groups were homogeneous in their overall writing performance. The test revealed no significant difference between them $(\mathrm{CWCF}$ Group: $(M d=5.00))$, (ITMF Group $(M d=5.00), \mathrm{U}=401.00$, $z=-.095, p=.92>.05$; however, it represented a very small effect $(\mathrm{r}=-.01)$ based on Cohen $(1988$, as cited in Pallant, 2013).

\section{Findings of the Research Questions}

First, the Mann-Whitney U Test, which was run to compare the posttests in CWCF and ITMF groups, revealed a significant difference in the overall quality of the groups' argumentative essays (CWCF Group: $(M d=6.00)$ ), (ITMF Group $(M d=7.00), \mathrm{U}=123.000, z=-4.735, p=.000, \mathrm{r}=-.62$. The median scores showed that the ITMF outperformed the CWCF and the found effect size was large, based on Cohen (1988, as cited in Pallant, 2013).

Then, another Mann-Whitney U Test was run to compare the delayed-posttests in CWCF and ITMF groups to find out whether or not the found difference between groups vary over time. The test indicated that the two groups were still significantly different and the ITMF was still superior in their overall quality of their argumentative essays (CWCF Group: $(M d=6.00))$, (ITMF Group $(M d=7.00), \mathrm{U}=113.500$ $z=-4.957, p=.000, \mathrm{r}=-.65$. The median scores also showed no change. Additionally, a large effect size was found.

Finally, because the ITMF was found to be superior in their overall quality of their essays, a Wilcoxon Signed Rank Test was run to compare the posttest and delayed-posttest of this group to reveal whether or not there would be any significant change in it in the long term. The test showed no significant difference: $z=-1.41, p=.15$; the median scores indicated no change $(M d=7.00)$; however, the calculation of the effect size represented below medium effect size $(r=-.26)$.

\section{DISCUSSION AND CONCLUSION}

The superiority of ITMF over the CWCF, which was found in this study, can be attributed to several issues because several techniques collaborated, so the ITMF has yielded this positive result. The mentioned factors will be explained in the following paragraphs.

To begin with, with regard to the effect of the screencast video feedback on improving students' overall writing performance, the findings of this study are congruent with other research done into this issue (Ali, 2016; Cumming, 2015; Liou \& Peng, 2009; Parton, Crain-Dorough, \& Hancock, 2010) and support the scholars who recommend using screencasting technology (Cranny, 2016; Jones et al., 2012; Séror, 2012; Thompson \& Lee, 2012).

The findings can also be considered as consistent with the beliefs on the effectiveness of encouraging the learners to use learning strategies of keeping an error book or personal reflective notes, which facilitate the processing of the feedback and help the learners improve their writing ability (Guénette, 2012; Han \& Hyland, 2015; F. Hyland, 2003; Lee, 2013; Soltanpour \& Valizadeh, 2017; Suzuki, 2012; Van Beuningen, 2010).

Additionally, the findings corroborate the belief that if the learners' differences, such as their different needs and learning styles, are satisfied by the utilized educational technique in the classroom, such as the video feedback in the present study, beneficial effects will be exerted (Afrilyasanti, Cahyono, \& Astuti, 2016; Chen et al., 2016; Cohen, 2012; Dörnyei, 2005; Evans et al., 2010; Ferris, 2010; F. Hyland, 1998, 2000; K. Hyland \& Hyland, 2006b; Johnson \& Cooke, 2016; Katayama, 2007; Leki, 1991; Mayer \& Moreno, 2003; Oladejo, 1993; Silva, 2012; Thompson \& Lee, 2012).

Furthermore, what has been found supports the effectiveness of actively engaging the learners, so that they would not be the passive recipients of the feedback, rather they undertake responsibility for their learning (Ashwell, 2000; Baepler, Walker, \& Driessen, 2014; Basal, 2015; Davies, Dean, \& Ball, 2013; Ellis, 2010; Ferris, 2001, 2006; Guénette, 2012; Havnes et al., 2012; F. Hyland, 2001; Lalande, 1982; Lee, 1997, 2013; Muldrow, 2013; O’Flaherty \& Phillips, 2015; Saito, 1994). As an example, the effectiveness of revision assignment can be mentioned, which is consistent with Swain's (1985, 1995) Output Hypothesis; associating this hypothesis with the current study's conditions and results, it can be stated that in this study, the learners were pushed to produce challenging output, so their awareness of linguistic input and gaps was raised and thus their progress towards the target language was facilitated. In addition, the effectiveness of noticing the importance of input in promoting linguistic processing in learners' L2 development is also corroborated by Schmidt's (1990, 1995, 2001) Noticing Hypothesis and some other scholars such as Tomlin and Villa (1994) as well as Robinson (1995); the revision requirement, therefore, which is strongly recommended by several scholars (e.g., Ellis, 2010; Ferris, 2004, 2010; Guénette, 2012; Sachs $\&$ Polio, 2007) as a helpful and perhaps necessary intermediate step toward the long-term acquisition of a specific feature (Ferris, 2004, 2010; Guénette, 2012; Sachs \& Polio, 2007), proved to be helpful in the present study.

Moreover, the findings prove the effectiveness of teacher-learner interaction and face-to-face negotiation relevant to the feedback to reduce the misunderstandings, as is in 
line with Long's (1996) Interaction Hypothesis and highly recommended by several scholars (Conrad \& Goldstein, 1999; Han \& Hyland, 2015; Hedgcock \& Lefkowitz, 1994; K. Hyland, 2009; Lee, 2013; Matsumura \& Hann, 2004; Nassaji, 2011; Nicol, 2010; Pica, 1994; Williams \& Severino, 2004). Through the process of negotiation, the participants in the ITMF group were able to understand not only the importance of the writing task and feedback but also their own strengths and weaknesses; they could also learn what to "do to close the gaps (i.e., improve the weaknesses) in their writing" (Lee, 2014, p. 204). This view is corroborated with the sociocultural paradigm for providing feedback which focuses on tailoring the feedback to the learners' ZPD, through a negotiated and graduated (i.e., adjusted to the level of the individual learner) process so that it would assist learning and also learners to self-correct (Aljaafreh \& Lantolf, 1994).

In conclusion, it can be said that through the ITMF, both cognitive apprenticeship and scaffolding occurred; like what Nyikos and Hashimoto (1997) explained, in this study, the students were engaged in reflective thinking and were required to monitor their performance. The responsibility for learning was mainly on the learner, but the teacher, also as the more knowledgeable person, had the responsibility of offering the learner support to facilitate the process of learning because as Benko (2012) stated, scaffolding is essential for tasks which are beyond students' independent language abilities. Moreover, the different functions of interactional modifications, such as providing a condition for the learners to receive comprehensible input, produce modified output, and notice the gaps in their knowledge could help them restructure their interlanguages (Mackey, 2012).

\section{DELIMITATION OF THIS STUDY AND SUGGESTIONS FOR FURTHER RESEARCH}

As the concluding remarks, three points need to be mentioned:

First, it should be noted that this research was conducted in general English classes where the learners study all the skills, not just writing, so the results may not necessarily be generalizable to the context of advanced writing classes and students who attend them; despite this, the essay writing lecturers and instructors are highly recommended trying this technique not only in their classes but also as a replication study in their own context.

Next, as it was mentioned before, revision following feedback has been highly recommended (Ferris, 2004, 2010; Guénette, 2012; Sachs \& Polio, 2007) and also proved to be beneficial (Chandler, 2003; Van Beuningen, De Jong, \& Kuiken, 2012). Nevertheless, as Shintani and Ellis (2015) claimed, it is also possible that feedback can be effective even if there is no opportunity to revise albeit on the condition that learners are required to pay attention to and process the corrections they have been provided with. Therefore, another study can be done considering this point. ITMF can be provided under the condition of either just paying attention to the corrections without revision requirement or being required to revise the texts after receiving the feedback.
Finally, a qualitative study is crucial to investigate the students' attitudes and expectations towards the purpose and value of the ITMF with the aims of first, exploring their attitudinal engagement, which was recommended by Ellis (2010), and second, finding out some information about their individual differences (IDs) via analyzing their statements in order to understand how they can be helped to do the writing task better (K. Hyland, 2009) because the IDs in behavioral engagement with the feedback were already proved (Ferris, Liu, Sinha, \& Senna, 2013; Han \& Hyland, 2015; F. Hyland, 2003; Storch \& Wigglesworth, 2010). Moreover, to consider the dynamics of the affective engagement with the treatment, the investigation of the learners' attitudes had better be done not only during the treatment period of the study but also after finishing it because based on F. Hyland (2003), Storch and Wigglesworth (2010), Ferris et al., (2013), as well as Han and Hyland (2015), the learners emotional reactions to the received treatment may change during the study.

\section{REFERENCES}

AbdRahman, S., Salam, A., \& Yusof, M. (2014). Screencast feedback practice on students' writing. In Asia-Pacific Social Science Conference. Seoul, Korea: APSSC. Retrieved from https://www.researchgate.net/publication/289396637_Screencast_Feedback_Practice_on Students'_Writing

Afrilyasanti, $\bar{R} .$, Cahyono, B. Y., \& Astuti, U. P. (2016). Effect of flipped classroom model on Indonesian EFL students' writing ability across and individual differences in learning. International Journal of English Language and Linguistics Research, 4(5), 65-81. Retrieved from http://www.eajournals.org/wp-content/ uploads/Effect-Of-Flipped-Classroom-Model-on-Indonesian-EFL-Students'-Writing-Ability-Across-and-Individual-Differences-in-Learning.pdf

Ali, A. D. (2016). Effectiveness of using screencast Feedback on EFL students' writing and perception. English Language Teaching, 9(8), 106-121. https://dx.doi. org/10.5539/elt.v9n8p106

Aljaafreh, A., \& Lantolf, J. P. (1994). Negative feedback as regulation and second language learning in the zone of Proximal development. The Modern Language Journal, 78(4), 465-483. https://dx.doi. org/10.1111/j.1540-4781.1994.tb02064.x

Alkhatib, N. I. M. (2015). Written corrective feedback at a saudi university: English language teachers' beliefs, students 'preferences, and teachers 'practices. (Doctoral dissertation). University of Essex. Retrieved from repository.essex.ac.uk/15382/1/THESIS 6Oct pdf.

Ashwell, T. (2000). Patterns of teacher response to student writing in a multiple-draft composition classroom: Is content feedback followed by form feedback the best method? Journal of Second Language Writing, 9(3), 227-258. https://dx.doi.org/10.1016/S10603743(00)00027-8

Baepler, P., Walker, J. D., \& Driessen, M. (2014). It's not about seat time: Blending, flipping, and efficiency in active learning classrooms. Computers \& Education, 
78, 227-236. https://dx.doi.org/10.1016/j.compedu.2014.06.006

Basal, A. (2015). The implementation of a flipped classroom in foreign language teaching. Turkish Online Journal of Distance Education, 16(4), 28-37. https://dx.doi. org/10.17718/tojde. 72185

Benko, S. L. (2012). Scaffolding: An ongoing process to support adolescent writing development. Journal of Adolescent \& Adult Literacy, 56(4), 291-300. https:// dx.doi.org/10.1002/JAAL.00142

Bitchener, J. (2008). Evidence in support of written corrective feedback. Journal of Second Language Writing, 17(2), 102-118. https://dx.doi.org/10.1016/j.jslw.2007.11.004

Bitchener, J., \& Ferris, D. R. (2012). Written corrective feedback in second language acquisition and writing. New York, NY: Routledge.

Bruton, A. (2009). Improving accuracy is not the only reason for writing, and even if it were. System, 37(4), 600-613. https://dx.doi.org/10.1016/j.system.2009.09.005

Carless, D., Salter, D., Yang, M., \& Lam, J. (2011). Developing sustainable feedback practices. Studies in Higher Education, 36(4), 395-407. https://dx.doi. org/10.1080/03075071003642449

Chandler, J. (2003). The efficacy of various kinds of error feedback for improvement in the accuracy and fluency of L2 student writing. Journal of Second Language Writing, 12(3), 267-296. https://dx.doi.org/10.1016/ S1060-3743(03)00038-9

Chapelle, C. A. (2005). Interactionist SLA theory in CALL research. In J. L. Egbert \& G. M. Petrie (Eds.), CALL research perspectives (pp. 53-64). Mahwah, New Jersey: Lawrence Erlbaum Associates, Inc.

Chen, S., Nassaji, H., \& Liu, Q. (2016). EFL learners' perceptions and preferences of written corrective feedback: A case study of university students from Mainland China. Asian-Pacific Journal of Second and Foreign Language Education, 1(5), 1-17. https://dx.doi.org/10.1186/ s40862-016-0010-y

Cohen, A. D. (2012). Strategies: The interface of styles, strategies, and motivation on tasks. In S. Mercer, R. Stephen, \& M. Williams (Eds.), Psychology for language learning: Insights from research, theory and practice (pp. 136-150). Basingstoke, England: Palgrave Macmillan.

Cohen, A. D., \& Cavalcanti, M. (1990). Feedback on written compositions: Teacher and student verbal reports. In B. Kroll (Ed.), Second Language Writing: Research Insights for the Classroom (pp. 155-177). Cambridge, UK: Cambridge University Press.

Conrad, S. M., \& Goldstein, L. (1999). Student revision after teacher written comments: Text, contexts and individuals. Journal of Second Language Writing, 8(2), 147-180. https://dx.doi.org/10.1016/S1060-3743(99)80126-X

Cranny, D. (2016). Screencasting, a tool to facilitate engagement with formative feedback? All Ireland Journal of Teaching and Learning in Higher Education (AISHE-J), 8(3), 2911-2937. Retrieved from http://ojs.aishe.org/index.php/aishe-j/article/view/291/497
Crews, T. B., \& Wilkinson, K. (2010). Students' perceived preference for visual and auditory assessment with e-handwritten feedback. Business Communication Quarterly, 73(4), 399-412. https://dx.doi. org/10.1177/1080569910385566

Crook, A., Mauchline, A., Maw, S., Lawson, C., Drinkwater, R., Lundqvist, K., Orsmond, P., Gomez, S., \& Park, J. (2012). The use of video technology for providing feedback to students: Can it enhance the feedback experience for staff and students? Computers and Education, 58(1), 386-396. https://dx.doi.org/10.1016/j.compedu. 2011.08 .025

Cumming, A. (1995). Fostering writing expertise in ESL composition instruction: Modeling and evaluation. In D. Belcher \& G. Braine (Ed.), Academic writing in a second language: Essays on research and pedagogy (pp. 375-397). Norwood, NJ: Ablex.

Cumming, A. (2015). Using audio screencast for feedback on short written essays. (Doctoral dissertation). Southern Illinois University Carbondale. Retrieved from https:// search.proquest.com/pqdtglobal/docview/1734464616/ fulltextPDF/88410B9D8DB24C06PQ/2?accountid $=39519$

Davies, R. S., Dean, D. L., \& Ball, N. (2013). Flipping the classroom and instructional technology integration in a college-level information systems spreadsheet course. Educational Technology Research and Development, 61(4), 563-580. https://dx.doi.org/10.1007/s11423-0139305-6

Denton, P., Madden, J., Roberts, M., \& Rowe, P. (2008). Students' response to traditional and computer-assisted formative feedback: A comparative case study. British Journal of Educational Technology, 39(3), 486-500. https://dx.doi.org/10.1111/j.14678535.2007.00745.x

Diab, R. L. (2005a). EFL university students' preferences for error correction and teacher feedback on writing. TESL Reporter, 38(1), 27-51. Retrieved from https:/laur.lau. edu.lb:8443/xmlui/bitstream/handle/10725/2796/EFL. pdf? sequence $=1 \&$ isAllowed $=y$

Diab, R. L. (2005b). Teachers' and students' beliefs about responding to ESL writing: A case study. TESL Canada, 23(1), 28-43. https://dx.doi.org/10.18806/tesl.v23i1.76

Dörnyei, Z. (2005). The psychology of the language learner: Individual differences in second language acquisition. Mahwah, NJ: Lawrence Erlbaum.

Ellis, R. (1999). Learning a second language through interaction. Amsterdam: John Benjamins.

Ellis, R. (2009a). A typology of written corrective feedback types. English Language Teaching, 63(2), 97-107. https://dx.doi.org/10.1093/elt/ccn023

Ellis, R. (2009b). Corrective feedback and teacher development. L2 Journal, 1, 3-18. Retrieved from http://epi. sc.edu/ar/AS_4_files/Ellis, 2009.pdf

Ellis, R. (2010). EPILOGUE: A framework for investigating oral and written corrective feedback. Studies in Second Language Acquisition, 32(2), 335-349. https://dx.doi. org/10.1017/S0272263109990544 
Ellis, R., \& Shintani, N. (2014). Exploring language pedagogy through second language acquisition research. New York, NY: Routledge.

Ene, E., \& Upton, T. A. (2014). Learner uptake of teacher electronic feedback in ESL composition. System, 46(1), 80-95. https://dx.doi.org/10.1016/j.system.2014.07.011

Evans, N. W., Hartshorn, K. J., McCollum, R. M., \& Wolfersberger, M. (2010). Contextualizing corrective feedback in second language writing pedagogy. Language Teaching Research, 14(4), 445-463. https://dx.doi. org/10.1177/1362168810375367

Ferris, D. R. (1995). Student reactions to teacher response in multiple-draft-composition classrooms. TESOL Quarterly, 29(1), 33-53. https://dx.doi.org/10.2307/3587804

Ferris, D. R. (2001). Teaching writing for academic purposes. In J. Flowerdew \& M. Peacock (Eds.), Research perspectives on English for academic purposes (pp. 298314). Cambridge, UK: Cambridge University Press.

Ferris, D. R. (2003). Response to student writing: Implications for second language students. Mahwah, NJ: Lawrence Erlbaum Associates.

Ferris, D. R. (2004). The "grammar correction" debate in L2 writing: Where are we, and where do we go from here? (and what do we do in the meantime...?). Journal of Response to Writing, 13(1), 49-62. https://dx.doi. org/10.1016/j.jslw.2004.04.005

Ferris, D. R. (2006). Does error feedback help student writers? New evidence on the short- and long-term effects of written error correction. In K. Hyland \& F. Hyland (Ed.), Feedback in second language writing: Contexts and issues (pp. 81-104). Cambridge, UK: Cambridge University Press.

Ferris, D. R. (2010). Second language writing research and written corrective feedback in SLA: Intersections and practical applications. Studies in Second Language Acquisition, 32(2), 181-201. https://dx.doi.org/10.1017/ S0272263109990490

Ferris, D. R. (2014). Responding to student writing: Teachers' philosophies and practices. Assessing Writing, 19, 6-23. https://doi.org/10.1016/j.asw.2013.09.004

Ferris, D. R., Liu, H., Sinha, A., \& Senna, M. (2013). Written corrective feedback for individual L2 writers. Journal of Second Language Writing, 22(3), 307-329. https:// dx.doi.org/10.1016/j.jslw.2012.09.009

Ferris, D. R., \& Roberts, B. (2001). Error feedback in L2 writing classes: How explicit does it need to be? Journal of Second Language Writing, 10(3), 161-184. https:// doi.org/10.1016/S1060-3743(01)00039-X

Field, A. (2013). Discovering statistics using SPSS (4 ${ }^{\text {th }}$. ed.). London: Sage.

Goldstein, L., \& Conrad, S. M. (1990). Student input and negotiation of meaning in ESL writing conferences. TESOL Quarterly, 24(3), 443-460. https://dx.doi. org/10.2307/3587229

Grami, M. (2005). The effect of teachers' written feedback on ESL students' perception: A study in a Saudi ESL university-level context. Annual Review of Education, Communication and Language Sciences, 2, 18-41. Re- trieved from http://research.ncl.ac.uk/ARECLS/vol2 documents/Grami/grami.htm

Guénette, D. (2007). Is feedback pedagogically correct? Research design issues in studies of feedback on writing. Journal of Second Language Writing, 16(1), 40-53. https://dx.doi.org/10.1016/j.jslw.2007.01.001

Guénette, D. (2012). The pedagogy of error correction: Surviving the written corrective feedback challenge. TESL CANADA JOURNAL/REVUE TESL DU CANA$D A, 30(1), 117-126$. https://dx.doi.org/10.18806/tesl. v30i1.1129

Hajian, L., Farahani, A. A. K., \& Shirazi, M. A. (2014). A study of students' and teachers' preferences and attitudes towards correction of classroom written errors in Iranian EFL context. International Journal of Applied Linguistics \& English Literature, 3(5), 287-297. https:// dx.doi.org/10.7575/aiac.ijalel.v.3n.5p.287

Hamouda, A. (2011). A study of students and teachers' preferences and attitudes towards correction of classroom written errors in Saudi EFL context. English Language Teaching, 4(3), 128-141. https://dx.doi.org/10.5539/elt. $\mathrm{v} 4 \mathrm{n} 3 \mathrm{p} 128$

Han, Y., \& Hyland, F. (2015). Exploring learner engagement with written corrective feedback in a Chinese tertiary EFL classroom. Journal of Second Language Writing, 30,31-44. https://dx.doi.org/10.1016/j.jslw.2015.08.002

Hartshorn, K. J., Evans, N. W., Merrill, P. F., Sudweeks, R. R., Strong-Krause, D., \& Anderson, N. J. (2010). Effects of dynamic corrective feedback on ESL writing accuracy. TESOL Quarterly, 44(1), 84-109. https://dx.doi. org/10.5054/tq.2010.213781

Havnes, A., Smith, K., Dysthe, O., \& Ludvigsen, K. (2012). Formative assessment and feedback: Making learning visible. Studies in Educational Evaluation, 38(1), 2127. https://dx.doi.org/10.1016/j.stueduc.2012.04.001

Hayes, J. R. (1996). A new framework for understanding cognition and affect in writing. In C. M. Levy \& S. Ransdell (Eds.), The science of writing: Theories, methods, individual differences and applications (pp. 1-27). Hillsdale, NJ: Lawrence Erlbaum Associates.

Hedgcock, J., \& Lefkowitz, N. (1994). Feedback on feedback: Assessing learner receptivity to teacher response in L2 composing. Journal of Second Language Writing, 3(2), 141-163. https://dx.doi.org/10.1016/10603743(94)90012-4

Hedgcock, J., \& Lefkowitz, N. (1996). Some input on input: Two analyses of student response to expert feedback in L2 writing. The Modern Language Journal, 80(3), 287-308. https://dx.doi.org/10.1111/j.1540-4781.1996. tb01612.x

Henderson, M., \& Phillips, M. (2015). Video-based feedback on student assessment: Scarily personal. Australasian Journal of Educational Technology, 31(1), 51-66. https://dx.doi.org/10.14742/ajet.v0i0.1878

Hyland, F. (1998). The impact of teacher written feedback on individual writers. Journal of Second Language Writing, 7(3), 255-286. https://dx.doi.org/10.1016/S10603743(98)90017-0 
Hyland, F. (2000). ESL writers and Feedback: Giving more autonomy to students. Language Teaching Research, 4(1), 33-54. https://dx.doi. org/10.1177/136216880000400103

Hyland, F. (2001). Providing effective support: Investigating feedback to distance language learners. Open Learning: The Journal of Open and Distance Learning, 16(3), 233-247. https://dx.doi org/10.1080/02680510120084959

Hyland, F. (2003). Focusing on form: Student engagement with teacher feedback. System, 31(2), 217-230. https:// dx.doi.org/10.1016/S0346-251X(03)00021-6

Hyland, F. (2010). Future directions in feedback on second language writing: Overview and research agenda. International Journal of English Studies, 10(2), 171182. Retrieved from http://revistas.um.es/ijes/article/ view/119251

Hyland, K. (2009). Teaching and researching writing ( $2^{\text {nd }}$ ed.). Harlow, UK: Pearson Education Limited.

Hyland, K., \& Hyland, F. (2006a). Feedback on second language students' writing. Language Teaching, 39(2), 83 https://dx.doi.org/10.1017/S0261444806003399

Hyland, K., \& Hyland, F. (2006b). Interpersonal aspects of response: Constructing and interpreting teacher written feedback. In K. Hyland \& F. Hyland (Eds.), Feedback in second language writing: Contexts and issues (pp. 206224). Cambridge, UK: Cambridge University Press.

Johnson, G. M., \& Cooke, A. (2016). Self-regulation of learning and preference for written versus audio-recorded feedback by distance education students. Distance Education, 37(1), 107-120. https://dx.doi.org/10.1080/ 01587919.2015.1081737

Jones, N., Georghiades, P., \& Gunson, J. (2012). Student feedback via screen capture digital video: Stimulating student's modified action. Higher Education, 64(5), 593-607. https://dx.doi.org/10.1007/s10734012-9514-7

Katayama, A. (2007). Japanese EFL students' preferences toward correction of classroom oral errors. Asian EFL Journal, 9(4). Retrieved from http://www.asian-efl-journal.com/Dec_2007_ak.php

Kellogg, R. T. (1996). A model of working memory in writing. In C. M. Levy \& S. Ransdell (Eds.), The science of writing: Theories, methods, individual differences and applications (pp. 57-71). Mahwah, NJ: Lawrence Erlbaum Associates.

Kormos, J. (2012). The role of individual differences in L2 writing. Journal of Second Language Writing, 21(4), 390-403. https://dx.doi.org/10.1016/j.jslw.2012.09.003

Lalande, J. F. (1982). Reducing composition errors: An experiment. The Modern Language Journal, 66(2), 140-149. https://dx.doi.org/10.1111/j.1540-4781.1982. tb06973.x

Larson-Hall, J. (2010). A guide to doing statistics in second language research using SPSS. New York, NY: Routledge.

Lee, I. (1997). ESL learners' performance in error correction in writing: Some implications for teaching. System,
25(4), 465-477. https://dx.doi.org/10.1016/S0346251X(97)00045-6

Lee, I. (2004). Error correction in L2 secondary writing classrooms: The case of Hong Kong. Journal of Second Language Writing, 13(4), 285-312. https://dx.doi. org/10.1016/j.jslw.2004.08.001

Lee, I. (2005). Error correction in the L2 writing classroom: What do students think? TESL Canada Journal, 22(2), 1-16. https://dx.doi.org/10.18806/tesl.v22i2.84

Lee, I. (2008). Understanding teachers' written feedback practices in Hong Kong secondary classrooms. Journal of Second Language Writing, 17(2), 69-85. https://dx. doi.org/10.1016/j.jslw.2007.10.001

Lee, I. (2013). Research into practice: Written corrective feedback. Language Teaching, 46(1), 108-119. https:// dx.doi.org/10.1017/S0261444812000390

Lee, I. (2014). Revisiting teacher feedback in EFL writing from sociocultural perspectives. TESOL Quarterly, 48(1), 201-213. https://dx.doi.org/10.1002/tesq.153

Leki, I. (1991). The preferences of ESL students for error correction in college-level writing classes. Foreign Language Annals, 24(3), 203-218. https://dx.doi. org/10.1111/j.1944-9720.1991.tb00464.x

Liou, H. C., \& Peng, Z. Y. (2009). Training effects on computer-mediated peer review. System, 37(3), 514-525. https://dx.doi.org/10.1016/j.system.2009.01.005

Long, M. H. (1996). The role of the linguistic environment in second language acquisition. In W. Ritchie \& T. Bhatia (Eds.), Handbook of second language acquisition (pp. 438-468). San Diego, CA: Academic Press.

Mackey, A. (2012). Input, interaction, and corrective feedback in L2 learning. Oxford, UK: Oxford University Press.

Mackey, A., \& Gass, S. M. (2005). Second language research: Methodology and design. Mahwah, New Jersey: Lawrence Erlbaum Associates, Inc.

Mahfoodh, O. H. A. (2017). "I feel disappointed": EFL university students' emotional responses towards teacher written feedback. Assessing Writing, 31, 53-72. https:// dx.doi.org/10.1016/j.asw.2016.07.001

Mahfoodh, O. H. A., \& Pandian, A. (2011). A qualitative case study of EFL students' affective reactions to and perceptions of their teachers' written feedback. English Language Teaching, 4(3), 14-27. https://dx.doi. org/10.5539/elt.v4n3p14

Manchón, R. M. (2009). Individual differences in foreign language: The dynanics of beliefs about L2 writing. RESLA, 22, 245-268. Retrieved from https://dialnet. unirioja.es/descarga/articulo/3138282.pdf

Manchón, R. M. (2011). Writing to learn the language: Issues in theory and research. In R. M. Manchón (Ed.), Learning-to-write and writing-to-learn in an additional language (pp. 61-84). Amsterdam: John Benjamins Publishing Company.

Matsumura, A., \& Hann, G. (2004). Computer anxiety and students' preferred feedback methods in EFL writing. The Modern Language Journal, 88(3), 403-415. https:// dx.doi.org/10.1111/j.0026-7902.2004.00237.x 
Mayer, R. E., \& Moreno, R. (2003). Nine ways to reduce cognitive load in multimedia learning. Educational Psychologist, 38(1), 43-52. https://dx.doi.org/10.1207/ S15326985EP3801_6

McMartin-Miller, C. (2014). How much feedback is enough?: Instructor practices and student attitudes toward error treatment in second language writing. Assessing Writing, 19, 24-35. https://dx.doi.org/10.1016/j.asw.2013.11.003

Muldrow, K. (2013). A new approach to language instruction: Flipping the classroom. The Language Educator, (November), 28-31. Retrieved from https://www.actfl.org/sites/ default/files/pdfs/TLE_pdf/TLE_Nov13_Article.pdf

Nassaji, H. (2011). Correcting students' written grammatical errors: The effects of negotiated versus nonnegotiated feedback. Studies in Second Language Learning and Teaching, 1(3), 315-334. https://dx.doi.org/10.14746/ssllt.2011.1.3.2

Nicol, D. (2010). From monologue to dialogue: Improving written feedback processes in mass higher education. $A s-$ sessment \& Evaluation in Higher Education, 35(5), 501517. https://dx.doi.org/10.1080/02602931003786559

Nyikos, M., \& Hashimoto, R. (1997). Constructivist Theory Applied to Collaborative Learning in Teacher Education: In Search of ZPD. The Modern Language Journal, 81(4), 506-517. https://dx.doi.org/10.1111/j.1540-4781.1997. tb05518.x

O'Flaherty, J., \& Phillips, C. (2015). The use of flipped classrooms in higher education: A scoping review. The Internet and Higher Education, 25, 85-95. https://dx. doi.org/10.1016/j.iheduc.2015.02.002

Oladejo, J. A. (1993). Error correction in ESL: Learners' preferences. TESL Canada Journal, 10(2), 71-89. https://dx.doi.org/10.18806/tesl.v10i2.619

Pallant, J. (2013). SPSS survival manual: A step by step guide to data analysis using IBM SPSS ( $5^{\text {th }}$ ed.). Berkshire, England: Open University Press.

Parton, B. S., Crain-Dorough, M., \& Hancock, R. (2010). Using flip camcorders to create video feedback: Is it realistic for professors and beneficial to students? International Journal of Instructional Technology \& Distance Learning, 7(1), 15-23. Retrieved from http://www.itdl. org/Journal/Jan_10/article02.htm

Pica, T. (1994). Research on negotiation: What does it reveal about second-language learning conditions, processes, and outcomes? Language Learning, 44(3), 493-527. https://dx.doi.org/10.1111/j.1467-1770.1994.tb01115.x

Robinson, P. (1995). Attention, memory and the "noticing" hypothesis. Language Learning, 45(2), 283-331. https:// dx.doi.org/10.1111/j.1467-1770.1995.tb00441.x

Sachs, R., \& Polio, C. (2007). Learners' uses of two types of written feedback on a L2 writing revision task. Studies in Second Language Acquisition, 29(1), 67-100. https:// dx.doi.org/10.10170S0272263107070039

Saito, H. (1994). Teachers' practices and students' preferences for feedback on second language writing: A case study of adult ESL learners. TESL Canada Journal, 11(2), 46-70. https://dx.doi.org/10.18806/tesl.v11i2.633

Saslow, J., \& Ascher, A. (2012). Summit 1 ( $2^{\text {nd }}$ ed.). New York, NY: Pearson Education.
Schmidt, R. W. (1990). The role of consciousness in second language learning. Applied Linguistics, 11(2), 129-158. https://dx.doi.org/10.1093/applin/11.2.129

Schmidt, R. W. (1995). Consciousness and foreign language learning: A tutorial on the role of attention and awareness in learning. In R. W. Schmidt (Ed.), Attention and awareness in foreign language learning and teaching (pp. 1-63). Honolulu, HI: University of Honolulu.

Schmidt, R. W. (2001). Attention. In P. Robinson (Ed.), Cognition and second language instruction (pp. 3-32). Cambridge, UK: Cambridge University Press.

Séror, J. (2012). Show me! Enhanced feedback through screencasting technology. TESL Canada Journal, 30(1), 104-116. https://dx.doi.org/10.18806/tesl.v30i1.1128

Sheen, Y. (2011). Corrective feedback, individual differences and second language learning. New York: Springer.

Sheppard, K. (1992). Two feedback types: Do they make a difference? RELC Journal, 23(1), 285-304. https://dx. doi.org/10.1177/003368829202300107

Shintani, N., \& Ellis, R. (2013). The comparative effect of direct written corrective feedback and metalinguistic explanation on learners' explicit and implicit knowledge of the English indefinite article. Journal of Second Language Writing, 22(3), 286-306. https://dx.doi. org/10.1016/j.jslw.2013.03.011

Shintani, N., \& Ellis, R. (2015). Does language analytical ability mediate the effect of written feedback on grammatical accuracy in second language writing? System, 49, 110-119. https://dx.doi.org/10.1016/j.system.2015.01.006

Silva, M. L. (2012). Camtasia in the classroom: student attitudes and preferences for video commentary or microsoft word comments during the revision process. Computers and Composition, 29(1), 1-22. https://dx.doi. org/10.1016/j.compcom.2011.12.001

Soltanpour, F., \& Valizadeh, M. (2017). The effect of the collaboration of reflective notes with CALL on EFL learners' writing accuracy. European Journal of English Language Teaching, 2(2), 22-52. https://dx.doi. org/10.5281/zenodo.495361

Storch, N. (2010). Critical feedback on written corrective feedback research. International Journal of English Studies, 10(2), 29-46. Retrieved from https://dialnet. unirioja.es/descarga/articulo/3424315.pdf

Storch, N., \& Wigglesworth, G. (2010). Learners' processing, uptake, and retension of corrective feedback on writing: Case studies. Studies in Second Language Acquisition, 32, 303-334. https://dx.doi.org/10.1017/ S0272263109990532

Suzuki, W. (2012). Written languaging,direct correction, and second language writing revision. Language Learning, 62(4), 1110-1133. https://dx.doi.org/10.1111/j.14679922.2012.00720.x

Swain, M. (1985). Communicative competence: Some roles of comprehensible input and comprehensible output in its development. In S. M. Gass \& C. G. Madden (Eds.), Input in second language acquisition (pp. 64-81). Cambridge, UK: Cambridge University Press. 
Swain, M. (1995). Three functions of output in second language learning. In G. Gook \& B. Seidlhofer (Eds.), Principle and practice in applied linguistics (pp. 125-144). Oxford: Oxford University Press.

Thompson, R., \& Lee, M. J. (2012). Talking with students through screencasting: Experimentations with video feedback to improve student learning. The Journal of Interactive Technology and Pedagogy, February(1), 1-16. Retrieved from https://jitp.commons.gc.cuny.edu/ talking-with-students-through-screencasting-experimentations-with-video-feedback-to-improve-student-learning Tomlin, R., \& Villa, V. (1994). Attention in cognitive science and second language acquisition. Studies in Second Language Acquisition, 16(2), 183-203. https://dx.doi. org/10.1017/S0272263100012870

Van Beuningen, C. G. (2010). Corrective feedback in L2 writing: Theoretical perspectives, empirical insights, and future directions. International Journal of English Studies, 10(2), 1-27. Retrieved from http://revistas. um.es/ijes/article/view/119171
Van Beuningen, C. G., De Jong, N. H., \& Kuiken, F. (2012). Evidence on the effectiveness of comprehensive error correction in second language writing. Language Learning, 62(1), 1-41. https://dx.doi.org/10.1111/j.14679922.2011.00674.x

Warschauer, M. (2005). Sociocultural perspectives on CALL. In J. L. Egbert \& G. M. Petrie (Eds.), CALL research perspectives (pp. 41-52). Mahwah, New Jersey: Lawrence Erlbaum Associates, Inc.

Warschauer, M., Turbee, L., \& Roberts, B. (1996). Computer learning networks and student empowerment. System, 24(1), 1-14. https://dx.doi.org/10.1016/0346251X(95)00049-P

Williams, J., \& Severino, C. (2004). The writing center and second language writers. Journal of Second Language Writing, 13(3), 165-172. https://dx.doi.org/10.1016/j. jslw.2004.04.010

Zacharias, N. T. (2007). Teacher and student attitudes toward teacher feedback. RELC Journal, 38(1), 38-52. https:// dx.doi.org/10.1177/0033688206076157 